\title{
RUIZ, EL CRÍTICO
}

\author{
Ascanio Cavallo
}

Critico de cine

Resumen: La reciente publicación de Diario. Notas, recuerdos y secuencia de cosas vistas, de Raúl Ruiz, permite tener acceso a lo que el director pensaba de las películas que veía en su vida cotidiana. Ascanio Cavallo recopiló estas notas esparcidas a lo largo de los dos volúmenes que componen esta publicación.

Palabras clave: Raúl Ruiz, cine, diario.

\section{RUIZ AS CRITIC}

AвSTRACT: The recent publication of Raúl Ruiz's Diario. Notas, recuerdos y secuencia de cosas vistas has provided insights into what the director thought of the films he saw in his daily life. Ascanio Cavallo gleaned these scattered notes from the length of this twovolume publication.

KeYworDs: Raúl Ruiz, cinema, diary.

Ascanio Cavallo. Periodista de la Universidad de Chile. Columnista político del diario La Tercera y crítico de cine de la revista Sábado de El Mercurio. Director de la Colección Cine de Uqbar Editores. Ex director del diario La Época y de revista Hoy. Entre sus libros figuran La historia oculta del régimen militar, con Manuel Salazar y Óscar Sepúlveda (1988), y La historia oculta de la transición (1998). Email: ascanio.cavallo@tironiasociados.com.

Estudios Públicos agradece a Valeria Sarmiento, viuda de Raúl Ruiz, la autorización para reproducir aquí estos extractos del Diario. 


\begin{abstract}
A lo largo de los dos volúmenes de su Diario $^{1}$, Raúl Ruiz registra breves comentarios de las películas que ve, algunas de ellas en salas de cine y la mayoría en formatos caseros. En muchos casos son revisiones de cintas que conoció en el pasado. La siguiente es una recopilación de los comentarios que registra, ordenados por sus fechas de realización:
\end{abstract}

Las manos de Orlac (Orlacs Hände, Robert Wiene, 1924): "Una de las fábulas más crueles y fascinantes de la historia del cine". "Creo que se puede ir más lejos en la descomposición del cuerpo (justamente lo menos ajeno al resto del cuerpo son el tema y el pretexto del film)".

Gunga Din (George Stevens, 1939): "Racismo y colonialismo insoportable. No llegué al fin".

El ciudadano Kane (Citizen Kane, Orson Welles, 1941): "El final sigue siendo impresionante, sobre todo la escena en que su mujer lo deja y empieza a destruir la habitación y termina diciendo 'Rosebud"'.

Los verdugos también mueren (Hangmen also Die, Fritz Lang, 1943): "Impresiona la virtuosidad del guión y de la puesta en escena. Los actores alemanes actúan en el más puro estilo expresionista y los americanos, que representan al pueblo checo, en una especie de realismo al límite del recto tono. Juegos de luz y de sombra expresionista de J. Wong Howe que debieron parecer extemporáneos en la época y que hoy parecen funcionales. Bellísimos".

La venganza de la mujer pantera (Curse of the Cat People, Robert Wise y Gunther V. Fritsch, 1944): "Una réplica a La mujer pantera filmada a la manera de Tourneur. Atmósfera inquietante sin que nada lo sea particularmente. Un pueblito apacible de Estados Unidos. Una niñita soñadora. Una madre, antigua actriz, que vive con su hija, a la que acusa de impostora ('mi verdadera hija murió a los 6 años', dice, y la niñita soñadora tiene justamente 6 años)".

El ladrón de cuerpos (The Body Snatcher, Robert Wise, 1945): "Impecable y con mucha carga poética. Exploración del lugar común mediante la multiplicación de elipsis (el asesinato de la mendiga ciega,

${ }^{1}$ Raúl Ruiz, Diario. Notas, recuerdos y secuencias de cosas vistas (19932011), edición de Bruno Cuneo (Santiago: UDP, 2017). Este libro es reseñado por Cavallo en este mismo número de Estudios Públicos. 
mostrando la calle vacía y la voz de la mendiga que canta y simplemente deja de cantar)".

En legítima defensa (Quai des Orfèvres, Henri-Georges Clouzot, 1947): "Admirable documento de época: París sucio, frío, inhóspito y gris. Pura poesía (...) y una enorme humanidad. Cariño por la gente, hasta los más odiosos".

Arenas de Iwo Jima (Sands of Iwo Jima, Allan Dwan, 1949): “Admirable. Aprendí algunos trucos técnicos".

La heredera (The Heiress, William Wyler, 1949): "De largo aliento y más Wyler que Wyler".

Con las horas contadas (D.O.A., Rudolph Maté, 1949): "Curioso ejemplar de la serie $\mathrm{B}$, con decorados exteriores en las calles con verdaderos transeúntes. Una historia al límite de lo onírico".

Prisión (Fängelse, Ingmar Bergman, 1949): "Muchísimas ideas tiradas a la chuña, pero se siente lo que vendrá. La idea del mundo como infierno que tiene el profesor loco no es muy distinta de la que describe Swedenborg en Arcana Coelestia. El infierno es el mundo. La venida del demonio en gloria y majestad es inminente. Lo primero que va a hacer es juzgar al piloto que tiró la bomba atómica en Hiroshima como criminal de guerra. Prohibirá las bombas atómicas. Va a combatir la polución provocada por las industrias".

La ronda (La ronde, Max Ophüls, 1950): "Admirable y algo hostigosa, pero hay mucho que aprender del ritmo, a la vez nonchalant y tendu".

La muerte en un beso (In a Lonely Place, Nicholas Ray, 1950): "Como siempre, y sea cual sea el guionista, se las arregla para desorientar. La sospecha es más fuerte que la realidad. Humphrey Bogart está marcado de tal manera, que todo hace pensar que es un asesino, hasta tal punto que aunque no lo sea lo es".

Infierno en las nubes (Flying Leathernecks, Nicholas Ray, 1951): "Algo deshilvanada. Perezosa. Los combates aéreos, confusos. Es evidente que la mezcla de actualidades y ficción funciona menos en colores".

Los cuentos de Hoffmann (The Tales of Hoffmann, Michael Powell, 1951): "De un kitsch desarmante". 
Cuando me vaya (Tito Davison, 1954): "Lo recordaba de cuando tenía ocho años. Me habían quedado algunas imágenes fuertes. Descubrí con sorpresa que muchas imágenes-tableaux del film se las puede encontrar dispersas en muchas de mis películas (...). Al mismo tiempo el film es un ejemplo clarísimo de la estructura de un melodrama mexicano: no importa cuánto luches por conseguir algo. Si se te da es porque la divinidad lo habrá querido, independientemente de tus obras. En cierto sentido, más vale rogar y rezar que obrar (¿islam?, ¿protestantismo?)”.

Mr. Arkadin (Orson Welles, 1955): "Hacía unos cinco años que no la había vuelto a ver. Me gustó más. Se entiende su frescura de público porque transmite el poco interés por la intriga (problema que conozco) y sobre todo porque no hay personajes atractivos, sólo una situación en forma de círculo vicioso. En cierto sentido se la puede tomar como una alegoría de la Inquisición (Quiero saber todo sobre X, salvo que X soy yo mismo)".

Más corazón que odio (The Searchers, John Ford, 1956): "La carga de racismo y colonialismo es tan grande que no deja ver la virtuosidad narrativa y la eficacia de la puesta en escena".

Vértigo (Alfred Hitchcock, 1958): "Impresionante. Riqueza de recursos. Exceso que da la impresión de estilo simple, depurado. Dépouillement par l'excés".

Ben Hur (William Wyler, 1959): "No la había visto desde que salió, en los años 60. Impecable puesta en escena, salvo las bacanales, como siempre, con gusto a opereta. Diálogos ejemplares. Y hay discurso implícito. Los personajes empiezan a actuar como cristianos sin darse cuenta. Ben Hur se pregunta por qué salvó al centurión y el centurión se pregunta por qué salvó a Ben Hur".

La jetée (Chris Marker, 1962): "Sigue conservando un aspecto enigmático, que se compone bien con el romanticismo (viaje en el tiempo, historia de amor, estupor en los rostros, blanco y negro contrastados). La idea implícita es que vivimos en un mundo de loops, de sinfines que se ligan entre ellos según frecuencias diferentes".

El sirviente (The Servant, Joseph Losey, 1963): "Me pareció mucho menos surreal y más social, no estoy seguro qué sea mejor (...) Un poco como Godard, el exceso de percepción de los detalles me ha 
hecho perder la impresión de irrealidad mágica. De todas maneras un gran film".

El llanto del ídolo (This Sporting Life, Lindsay Anderson, 1963): "Académico, pero curioso en la economía de los hechos mostrados".

El desprecio (Le mépris, Jean-Luc Godard, 1963): "Sigo pensando que el film es sobre el desprecio del cine. Un emotivo homenaje a Fritz Lang".

La Gorgona (The Gorgon, Terence Fisher, 1964): "Recuperé el gusto por el cine torvo e ingenuo que solía ver a fines de los años 50 ".

Los códigos (Szyfry, Wojciech Has, 1966): "Película impresionante por su fuerza poética y su intransigencia".

Los rojos y los blancos (Csillagodok, katonák, Miklós Jancsó, 1967): "He conseguido recuperar un poco de modestia, lo que me permite aceptar que tengo mucho que aprender de Jancsó" [La verá de nuevo].

Una historia inmortal (Histoire inmortelle, Orson Welles, 1968): "Esta vez me di cuenta del equilibrio poético del montaje. Hay algunos silencios muy inspirados por los que circula una corriente subterránea que yo llamaría 'coral'. El eco de todas las historias contadas y 'mentidas' por los anónimos marineros. La luz algo aproximativa. Lo que había visto como pobreza (cheap) es rigor extremo".

Malpertuis (Harry Kümel, 1971): "Me impresionó mucho más que la primera vez. Renuncia a toda progresión dramática para privilegiar la atmósfera".

La puerta del cielo (Heaven's Gate -The director's cut, Michael Cimino, 1980): "Cuatro horas bastante sorprendentes. A ratos impresionante y sobre todo es muy bueno ver a un cineasta que se toma su tiempo en escenas en que se mofa de la narratividad obligatoria en nuestros días. Al salir quedé algo obnubilado".

¿Qué hora es? (Che ora é, Ettore Scola, 1989): “Algunas escenas de buen cine y mucho remplissage".

La nota azul (La note bleue, Andrzej Zulawsky, 1991): "Frenético y caótico, pero fascinante. Sólo que después de una media hora el tono tenso y galopante se vuelve monótono". 
El beso de la muerte (Kiss of Death, Barbet Schroeder, 1995): "Me dejó groggy y perplejo. La película me parece perfecta, pero transmite tal violencia y disgusto que no sé qué pensar".

Marcianos al ataque (Mars Attacks!, Tim Burton, 1996): “Aburrida y ruidosa. Tim Burton es un gagman, pero no un cineasta. Ninguna preocupación por el conjunto de signos: recarga y descarga sin dejar ninguna posibilidad de ver, porque no hay nada que ver. Los elementos no se asocian ni disocian. Efecto discoteca. Valeria y yo volvimos deprimidos".

El mundo perdido: Jurassic Park (The Lost World: Jurassic Park, Steven Spielberg, 1997): "Un horror. Infantilismo malsano, procaz".

Cara a cara (Face/Off, John Woo, 1997): "Ingeniosa, pero con el énfasis de los dibujos animados. No hay ninguna razón para que los zombies de Cahiers du Cinéma se sobreexciten (por muertos que estén)".

Hombres de negro (Men in Black, Barry Sonnenfeld, 1997): “A menudo, en las últimas películas de gran espectáculo, hay debajo de todo una idea loca que pronto es banalizada, pero que justifica el interés que despierta en el gran público. Aquí, los invasores de otros planetas están entre nosotros, pero son como trabajadores emigrados en espera de un permiso de trabajo".

Pequeños inquilinos (The Borrowers, Peter Hewitt, 1997): "Pasamos un buen momento: efectos especiales extraordinarios. Poesía, cero".

Contacto (Contact, Robert Zemeckis, 1997): "Perplejo por la fascinación que provocan los elementos adictivos y por el academicismo y la ausencia de emoción cinematográfica".

La celebración (Festen, Thomas Vinterberg, 1998): "Película de adolescentes en que juegan las imágenes video a la manera de un film de familia".

Shakespeare enamorado (Shakespeare in Love, John Madden, 1998): "Buen trabajo de Tom Stoppard, juego de espejos entre una comedia 'a lo Shakespeare' y el trabajo de escritura y montaje de Romeo y Julieta. Ligereza sospechosa". 
Ojos bien cerrados (Eyes Wide Shut, Stanley Kubrick, 1999): "Admirable a pesar de algunas faltas de gusto en la escena de la orgía (sobre todo el aspecto 'misa negra' revisada por Arias en el Folies Bergère, pero basta de maldades. Todo eso puede ser aplicado a mí con más pertinencia. Pero él era rico y yo no. Voilà)".

Belleza americana (American Beauty, Sam Mendes, 1999): "Sin interés".

Kedma (Amos Gitai, 2002): "Impresionante. Buena fisiología. El lugar y lo que tuvo lugar y lo que tiene lugar y siempre el lugar. ¿Qué es territorio sagrado? Enterrado, desterrado o encerrado y siempre aterrado. No hay territorio sin mesías".

La sonrisa de mi madre (L'ora di religione, Marco Bellocchio, 2002): "Debe ser uno de los films que persiste con más intensidad en combinar un clima onírico con una perspectiva política. Una vez más sin conseguirlo. $\mathrm{Y}$ sin embargo era para seguirlo. $\mathrm{Y}$ sin embargo esa persistencia en el error es parte constitutiva del mundo de Bellocchio, el cineasta italiano más cerca de Pirandello".

Sweet Sixteen (Ken Loach, 2002): "El Free Cinema está de vuelta: la misma indignación muy bien combinada con una atmósfera poética como las primeras películas de T. Richardson, de Karel Reisz y de... Ken Loach (...) El tránsito casi indiscernible de la infancia revoltosa al negocio del crimen. Poesía permanente".

El arca rusa (Russkiy kovcheg, Alexander Sokurov, 2002): "Hoy he tenido [un] shock profundo: el film de Sokurov es un hito en la historia del cine".

Tres noches de un sábado (Joaquín Eyzaguirre, 2002): "Me entretuvo por momentos, me interesó. Mucho material un poco demasiado encima, amontonado (...). El pecado original de todo el cine chileno y parte del latinoamericano es la falta de un principio dinámico de puesta en escena".

El gran ladrón (The good thief, Neil Jordan, 2002): "Hay más cine que en las últimas películas que hemos visto, pero no puede compararse con Bob, le flambeur, de J.-P. Melville, que le sirve de modelo. Simplemente porque Bob, le flambeur es un film más elegante, en el sentido de la palabra que les dan los matemáticos a ciertas demostraciones". 
El americano (The Quiet American, Philip Noyce, 2002): "Hay una sola (partícula alegórica): en un momento hay un atentado y el indirecto responsable, un agente de la CIA, de manera ambigua trata de ayudar y al mismo tiempo distanciarse de los hechos (la política exterior americana de aquellos años). Un americano saca su pañuelo y trata de limpiar la sangre que mancha sus zapatos. La imagen tiene algo de solecismo visual, que tanto interesaba a Klossowski: un símbolo que por su ambigüedad acentúa el enigma".

La guerra de los mundos (War of the Worlds, Steven Spielberg, 2005): "Una imagen que se me quedó: un tren de alta velocidad cruza la escena, el tren está en llamas".

La vida de los otros (Das Leben der Anderen, Florian Henckel von Donnersmarck, 2006): "Film académico, pero eficaz, sobre la Stasi y sus métodos para controlar el país. Buen manejo de la estructura en tres actos tal como la concibió y explicitó Ibsen: un policía rígido y de convicciones, cargado, transido de la panoplia de ideales comunistas: socialismo y tortura. Y luego sus ideales se van quebrando, horadados por pequeños incidentes. Sobre todo por el recuerdo sentimental de una infancia comunista, el recuerdo de poesías de Brecht, de la música de Eisler. La confrontación tácita con el poeta vigilado y perseguido. Novedades: el conflicto no es explícito y no pierde nunca su riqueza metafórica".

Belle toujours (Manoel de Oliveira, 2006): "Fuimos con Valeria (...). Nos gustó mucho a los dos. A mí me comunicó las ganas de filmar sobre La casa gótica [de Wilhelm Jensen]".

La Reina (The Queen, Stephen Frears, 2006): "Un verdadero festival de pintura académica y unos planos curiosos, pero todo lo que puede ser detestable y bien hecho". EP 